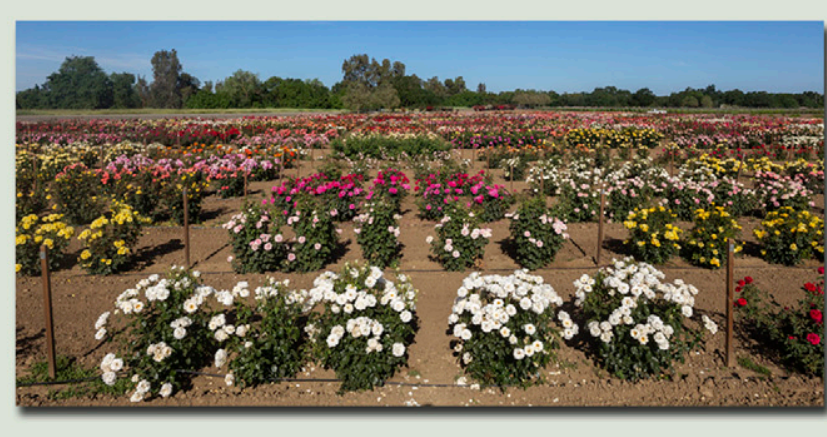

\title{
Economic Studies
}

\section{Reinforce Efforts to}

\section{Safeguard Specialty}

Crops in the United States

\section{Fuchs ${ }^{\dagger}$, C. V. Almeyda, M. Al Rwahnih, S. S. Atallah, E. J. Cieniewicz, K. Farrar, W. R. Foote, D. A. Golino, M. I. Gómez, S. J. Harper, M. K. Kelly, R. R. Martin, T. Martinson, F. M. Osman, K. Park, V. Scharlau, R. Smith, I. E. Tzanetakis, G. Vidalakis, and R. Welliver}

Keywords: clean plant center, clean planting material, diagnostics, disease management, disease prevention, economic cost, economic returns, National Clean Plant Network, pathogen-tested plant stocks, specialty crop production

Specialty crops are a vital segment of agriculture in the United States. Specialty crops are fruits and tree nuts, vegetables, culinary herbs and spices, medicinal plants, as well as nursery, floriculture, and horticulture crops (USDA-AMS 2020). In 2017, the value of farm level sales of specialty crops, including fruits, vegetables, and nursery crops, was estimated at close to $\$ 65$ billion or $38 \%$ of total crop sales in the United States. Approximately 240,000 farm operations produced more than 350 types of fruit, vegetable, tree nut, flower, nursery, and other horticultural crops (Johnson 2019).

Most specialty crops are clonally propagated. Clonal propagation ensures that propagated plants grow and produce fruits genetically identical to the original plant stock from which the planting materials are sourced (Bhiwani and Razdan 1996). In addition, most woody specialty crop plants are grown on a rootstock that provides tolerance to pests, diseases, and abiotic factors, confers adaptability to soil type, and impacts vigor, as well as influences fruit yield and quality (Castle 1995; Nimbolkar et al. 2016). Clonal propagation of rootstocks also assures identical genetic horticultural characteristics to the propagated progeny.

Graft-transmissible pathogens including viruses, viroids, bacteria, and phytoplasmas can cause detrimental diseases in clonally propagated specialty crops, such as berries (Martin et al. 2013, 2017; Polashock et al. 2017), citrus (Zhou et al. 2020), fruit trees (Ogawa et al. 1995; Rubio et al. 2017; Sutton et al. 2014), grapes (Fuchs 2020; Wilcox et al. 2015), hops (Pethybridge et al. 2008), roses (Horst and Cloyd 2007), and sweetpotatoes (Clark et al. 2013) (Table 1). If a plant stock (scion or rootstock) of one of these specialty crops is infected with a graft-transmissible pathogen, many of the propagated and grafted progeny will become infected. If pathogens are not identified in plant stocks using robust diagnostic methodologies for subsequent elimination of all propagative units that test positive, infected planting materials will be transferred to the field where they can contribute to disease outbreaks and epidemics. Similarly, top-working, root-grafting, and sometimes the use of contaminated tools (Barbosa et al. 2005) can contribute to the dissemination of graft-transmissible pathogens in the

${ }^{\dagger}$ Corresponding author: M. Fuchs; mf13@cornell.edu

Funding: USDA-APHIS (16-8130-0429-CA).

The author(s) declare no conflict of interest.

Accepted for publication 21 August 2020

() 2021 The American Phytopathological Society field. In addition, some viruses, phytoplasmas, and bacteria of specialty crops can be transmitted in the field by aerial arthropod vectors such as psyllids, aphids, mealybugs, soft scales, mites, whiteflies, treehoppers, and leafhoppers (Table 1). Some are also pollen-borne or transmitted by ectoparasitic dagger nematodes (Table 1) and viroids are mechanically transmissible, for instance in citrus (Barbosa et al. 2005) and hops (Pethybridge et al. 2008). Once an infection with a graft-transmissible pathogen has occurred, there is no cure in the field and management options are limited, relying primarily on reducing the level of inoculum and eventually controlling vector populations (Almeida et al. 2005, 2013; Clark et al. 2012; Ferguson and GraftonCardwell 2014; Fuchs 2020; Gabriel et al. 2020; Gergerich et al. 2015; Gibson and Kreuze 2015; Lee 2015; Maliogka et al. 2015; Martin et al. 2017; Ogawa et al. 1995; Olexa and Benn 2018; Pethybridge et al. 2008; Polashock et al. 2017; Rubio et al. 2017; Umer et al. 2019; Wilcox et al. 2015; Zhou et al. 2020).

Graft-transmissible diseases of specialty crops can be costly at the local, regional, or global scale. A comprehensive literature review recently summarized our collective knowledge on the economic impacts of diseases of specialty crops (Yeh et al. 2019). Here, we build on this review and describe how economic studies have identified profit-maximizing disease management solutions for some diseases. We then discuss collaborative research between agriculture economists, plant pathologists, extension educators, specialty crop growers, and regulators to develop and disseminate integrated recommendations on disease management strategies that resonate with growers. We also analyze studies on returns to investment in clean plant centers that produce, maintain, and distribute pathogen-tested propagative material with a special emphasis on centers of the National Clean Plant Network (NCPN). Finally, we discuss how additional economic studies could further incentivize the use of clean planting material and strengthen efforts to safeguard specialty crops in the United States.

\section{Diseases of Specialty Crops Can Be Costly}

Numerous graft-transmissible pathogens infect specialty crops. Some of these pathogens can cause diseases that are costly not only for the specialty crop sector but also for governmental agencies (Yeh et al. 2019). For example, in citrus, the economic impact of Huanglongbing (HLB or citrus greening) caused by Candidatus Liberibacter asiaticus is estimated at close to $\$ 9$ billion from 2006 to 2016 in Florida alone (Court et al. 2017; Hodges and Spreen 2012). The introduction of this invasive disease in Florida in 2005 resulted in a $40 \%$ reduction of citrus bearing hectares, a $57 \%$ decrease in the number of citrus operations, a $34 \%$ decrease in juice-processing 
Table 1. Select pathogens of importance as of 2020 to clean plant centers of the National Clean Plant Network (NCPN) with information on their taxonomic classification (family, genus, species name, and acronym), genome composition, morphology, and vectors

\begin{tabular}{|c|c|c|c|c|c|}
\hline Family $^{\mathbf{a}}$ & Genus $^{\mathbf{a}}$ & Species $^{a}$ & Genome & Morphology & Vector $^{\mathrm{c}}$ \\
\hline \multicolumn{6}{|l|}{ NCPN-Berries } \\
\hline Alphaflexiviridae & Potexvirus & Strawberry mild yellow edge virus (SMYEV) & (+)ssRNA & Filamentous & Aphids \\
\hline Betaflexiviridae & Carlavirus & Blueberry scorch virus (B1ScV) & (+)ssRNA & Filamentous & Aphids \\
\hline \multirow[t]{4}{*}{ Bromoviridae } & Ilarvirus & Apple mosaic virus (ApMV) & (+)ssRNA & Quasi-isometric & Pollen \\
\hline & & Blackberry chlorotic ringspot virus (BCRV) & & & \\
\hline & & Blueberry shock virus (BlShV) & & & \\
\hline & & Strawberry necrotic shock virus (SNSV) & & & \\
\hline \multirow[t]{4}{*}{ Caulimoviridae } & Badnavirus & Rubus yellow net virus (RYNV) & dsDNA & Bacilliform & Aphids \\
\hline & Caulimovirus & Strawberry vein banding virus (SVBV) & dsDNA & Spherical & Aphids \\
\hline & & Blueberry red ringspot virus (BRRV) & & & Unknown \\
\hline & & Blueberry fruit drop-associated virus $(\mathrm{BFDaV})$ & & & Unknown \\
\hline \multirow[t]{4}{*}{ Closteroviridae } & Closterovirus & Raspberry leaf mottle virus (RLMV) & (+)ssRNA & Filamentous & Aphids \\
\hline & Crinivirus & Strawberry pallidosis-associated virus $(\mathrm{SPaV})$ & (+)ssRNA & Filamentous & Whiteflies \\
\hline & & Beet pseudo-yellows virus (BPYV) & & & \\
\hline & & Blackberry yellow vein-associated virus (BYVaV) & & & \\
\hline Fimoviridae & Emaravirus & Blackberry leaf mottle-associated virus (BLMoaV) & $(-)$ ssRNA & Isometric & Mites \\
\hline Luteoviridae & Polerovirus & $\begin{array}{l}\text { Raspberry leaf blotch virus (RLBV) } \\
\text { Strawberry polerovirus } 1 \text { (SPV1) }\end{array}$ & $(-)$ ssRNA & Isometric & Aphids \\
\hline Potyviridae & Brambyvirus & Blackberry virus Y (BVY) & (-)SsRNA & Filamentous & Unknown \\
\hline \multirow[t]{2}{*}{ Rhabdoviridae } & Cytorhabdovirus & Strawberry crinkle virus (SCV) & (-)ssRNA & Bullet & Aphids \\
\hline & Unassigned & Raspberry vein chlorosis virus (RVCV) & $(-)$ ssRNA & Bullet & Aphids \\
\hline Reoviridae & Unassigned & Raspberry latent virus (RpLV) & dsRNA & Isometric & Aphids \\
\hline \multirow[t]{6}{*}{ Secoviridae } & Nepovirus & Blueberry leaf mottle virus (BLMoV) & $(+)$ ssRNA & Isometric & Dagger nematodes \\
\hline & & Tomato ringspot virus (ToRSV) & & & $\begin{array}{l}\text { Dagger nematodes, } \\
\text { pollen }\end{array}$ \\
\hline & & Tobacco ringspot virus (TRSV) & & & Dagger nematodes \\
\hline & Sadwavirus & Strawberry mottle virus (SMoV) & (+)ssRNA & Isometric & Aphids \\
\hline & & Black raspberry necrosis virus (BRNV) & & & Unknown \\
\hline & Unassigned & Strawberry latent ringspot virus (SLRSV) & (+)ssRNA & Isometric & Dagger nematodes \\
\hline Solemoviridae & Sobemovirus & Blueberry shoestring virus (BISSV) & (+)ssRNA & Isometric & Aphid \\
\hline Unassigned & Idaeovirus & Raspberry bushy dwarf (RBDV) & (+)ssRNA & Isometric & Pollen \\
\hline Unassigned & Blunervirus & Blueberry necrotic ring blotch virus (BNRBV) & (+)ssRNA & Unknown & Mites \\
\hline Xanthomonadaceae & Xylella & Xylella fastidiosa & dsDNA & Rod & $\begin{array}{l}\text { Leafhoppers, } \\
\text { spittlebugs }\end{array}$ \\
\hline \multirow[t]{4}{*}{ Acholeplasmataceae } & Phytoplasma & Candidatus Phytoplasma fragaria & dsDNA & N/A & Leafhoppers \\
\hline & & Candidatus Phytoplasma americanum & & & \\
\hline & & Candidatus Phytoplasma asteris & & & \\
\hline & & Candidatus Phytoplasma rubi & & & \\
\hline \multicolumn{6}{|l|}{ NCPN-Citrus } \\
\hline \multirow[t]{2}{*}{ Alphaflexivirdae } & Mandarivirus & Citrus yellow vein clearing virus (CYVCV) & $(+)$ ssRNA & Filamentous & $\begin{array}{l}\text { Aphids and } \\
\text { whiteflies }\end{array}$ \\
\hline & & Indian citrus ringspot virus ((ICRSV) & & & Unknown \\
\hline Aspiviridae & Ophiovirus & Citrus psorosis virus (CPsV) & $(-)$ ssRNA & Filamentous & Unknown \\
\hline \multirow[t]{3}{*}{ Betaflexiviridae } & Capillovirus & Apple stem grooving virus (ASGV) & (+)ssRNA & Filamentous & Unknown \\
\hline & Citrivirus & Citrus leaf blotch virus (CLBV) & (+)ssRNA & Filamentous & Unknown \\
\hline & & Citrus leaf blotch virus 2 (CLBV2) & & & \\
\hline \multirow[t]{2}{*}{ Bromoviridae } & Ilarvirus & Citrus variegation virus (CVV) & $(+)$ ssRNA & Quasi-isometric & Unknown \\
\hline & & Citrus leaf rugose virus (CLRV) & & & \\
\hline \multirow[t]{2}{*}{ Bunyavirales } & Coguvirus & Citrus concave gum-associated virus $(\mathrm{CCGaV})$ & $(-)$ ssRNA & Isometric & Unknown \\
\hline & & Citrus virus A (CiVA) & & & \\
\hline Caulimoviridae & Badnavirus & Citrus yellow mosaic virus (CYMV) & dsDNA & Bacilliform & Mealybug \\
\hline Closteroviridae & Closterovirus & Citrus tristeza virus (CTV) & $(+)$ ssRNA & Filamentous & Aphids \\
\hline Geminiviridae & Unassigned & Citrus chlorotic dwarf-associated virus $(\mathrm{CCDaV})$ & (+)ssRNA & & Whiteflies \\
\hline \multirow[t]{2}{*}{ Kitaviridae } & Cilevirus & Citrus leprosis virus C (CiLV-C) & (+)ssRNA & Bacilliform & Mites \\
\hline & & Citrus leprosis virus C2 (CiLV-C2) & & & \\
\hline Luteoviridae & Enamovirus & Citrus vein enation virus (CVEV) & (+)ssRNA & Isometric & Aphids \\
\hline \multirow[t]{3}{*}{ Rhabdoviridae } & Dichorhavirus & Citrus chlorotic spot virus (CiCSV) & (-)ssRNA & Rod & Mites \\
\hline & & Citrus leprosis $\mathrm{N}$ virus (CiLV-N) & & & \\
\hline & & Orchid fleck virus (OFV) & & & \\
\hline Secoviridae & Sadwavirus & Satsuma dwarf virus (SDV) & (+)ssRNA & Isometric & Unknown \\
\hline Tymoviridae & Marafivirus & Citrus sudden death-associated virus (CSDaV) & (+)ssRNA & Isometric & Unknown \\
\hline Pospiviroidae & Apscaviroid & Citrus bent leaf viroid (CBLVd) & ssRNA & N/A & N/A \\
\hline & Apscaviroid & Citrus dwarfing viroid (CDVd) & & & \\
\hline & Apscaviroid & Citrus viroid V (CVd V) & & & \\
\hline & Apscaviroid & Citrus viroid VI (CVd VI & & & \\
\hline
\end{tabular}

\footnotetext{
${ }^{a}$ Some of the taxonomic affiliations and virus names are tentative, as ratifications by the International Committee on Taxonomy of Viruses are pending.

${ }^{b}$ The shape of some virions is predicted by analogy with other viruses of the same genus or the same family rather than from actual electron micrograph observations.

${ }^{c}$ Some of the vectors are deduced by analogy with vectors of other viruses of the same genus rather than from conclusive transmission assays. N/A: not applicable.
} 
Table 1. (Continued from previous page)

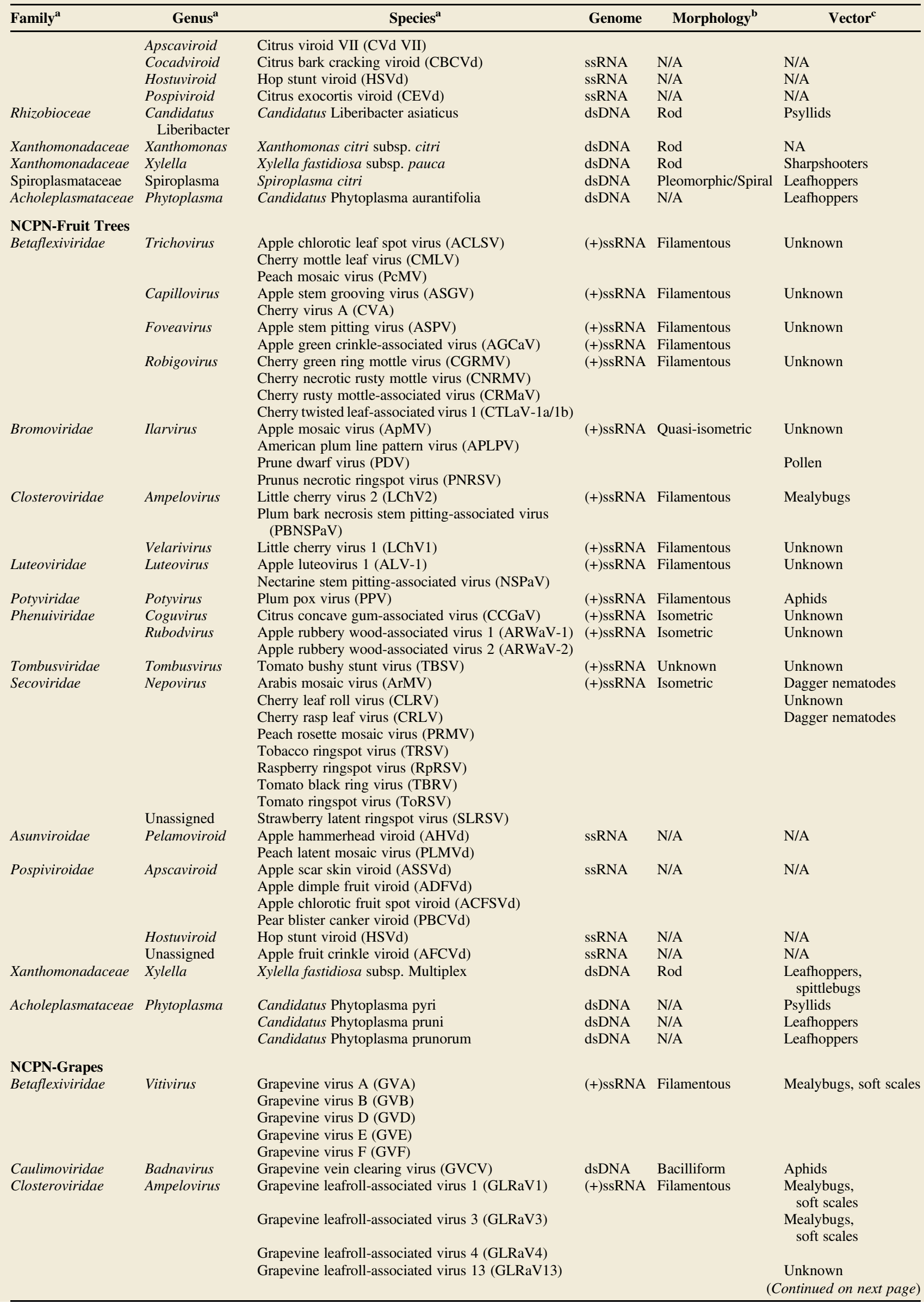


facilities and a loss of almost 8,000 full-time jobs by 2018 (Singerman 2019; USDA-NASS 2020). In California, the Citrus Pest and Disease Prevention Program spends over \$40 million annually to eradicate and suppress HLB and its vector, the Asian citrus psyllid (ACP, Diaphorina citri Kuwayama). Additionally, the United States Department of
Agriculture (USDA) has invested \$400 million for HLB suppression in eight years (McRoberts et al. 2019; Olexa and Benn 2018). A hypothetical $20 \%$ reduction in citrus bearing hectares due to HLB was predicted to result in more than 7,000 job losses and a reduction of $\$ 0.5$ billion in California's gross domestic product (Babcock 2018).

Table 1. (Continued from previous page)

\begin{tabular}{|c|c|c|c|c|c|}
\hline Family $^{\mathbf{a}}$ & Genus $^{a}$ & Species $^{\mathbf{a}}$ & Genome & Morphology & Vector $^{c}$ \\
\hline & Closterovirus & Grapevine leafroll-associated virus 2 (GLRaV2) & $(+)$ ssRNA & Filamentous & Unknown \\
\hline & Velarivirus & Grapevine leafroll-associated virus 7 (GLRaV7) & $(+)$ ssRNA & Filamentous & Unknown \\
\hline Geminiviridae & Grablovirus & Grapevine red blotch virus (GRBV) & ssDNA & Twinned & Treehopper \\
\hline \multirow[t]{14}{*}{ Secoviridae } & Nepovirus & Artichoke Italian latent virus (AILV) & $(+)$ ssRNA & Isometric & Unknown \\
\hline & & Arabis mosaic virus (ArMV) & & & Dagger nematode \\
\hline & & Blueberry leaf mottle virus (BBLMV) & & & Unknown \\
\hline & & Cherry leafroll virus (CLRV) & & & \\
\hline & & Grapevine Bulgarian latent virus (GBLV) & & & \\
\hline & & Grapevine deformation virus (GDeV) & & & \\
\hline & & Grapevine chrome mosaic virus (GCMV) & & & \\
\hline & & Grapevine fanleaf virus (GFLV) & & & Dagger nematode \\
\hline & & Grapevine Tunisian ringspot virus (GTRV) & & & Unknown \\
\hline & & Peach rosette mosaic virus (PRSM) & & & Dagger nematode \\
\hline & & Raspberry ringspot virus (RpRSV) & & & \\
\hline & & Tobacco ringspot virus (TRSV) & & & \\
\hline & & Tomato black ring virus (TBRV) & & & \\
\hline & Unassigned & Strawberry latent ringspot virus (SLRSV) & $(+)$ ssRNA & Isometric & Dagger nematodes \\
\hline \multirow[t]{5}{*}{ Tymoviridae } & Marafivirus & $\begin{array}{l}\text { Grapevine asteroid mosaic-associated virus } \\
\text { (GAMaV) }\end{array}$ & $(+)$ ssRNA & Isometric & Leafhoppers \\
\hline & & Grapevine rupestris vein feathering virus (GRVFV) & & & \\
\hline & & Grapevine Syrah virus 1 (GSyV1) & & & \\
\hline & Maculavirus & Grapevine fleck virus (GFkV) & $(+)$ ssRNA & Isometric & Unknown \\
\hline & & Grapevine redglobe virus (GRGV) & & & \\
\hline Xanthomonadaceae & Xylella & Xylella fastidiosa & dsDNA & Rod & $\begin{array}{r}\text { Leafhoppers, } \\
\text { spittlebugs }\end{array}$ \\
\hline \multirow[t]{5}{*}{ Acholeplasmataceae } & Phytoplasma & Candidatus Phytoplasma vitis & dsDNA & N/A & $\begin{array}{l}\text { Leafhoppers/ } \\
\text { Planthoppers }\end{array}$ \\
\hline & & Candidatus Phytoplasma solani & & & \\
\hline & & Candidatus Phytoplasma asteris & & & \\
\hline & & Candidatus Phytoplasma pruni & & & \\
\hline & & Candidatus Phytoplasma ulmi & & & \\
\hline \multicolumn{6}{|l|}{ NCPN-Hops } \\
\hline \multirow[t]{2}{*}{ Bromoviridae } & Ilarvirus & Apple mosaic virus (ApMV) & $(+)$ ssRNA & Quasi-isometric & Unknown \\
\hline & & Prunus necrotic ringspot virus (PNRSV) & & & \\
\hline \multirow[t]{3}{*}{ Betaflexiviridae } & Carlavirus & Hop mosaic virus (HpMV) & $(+)$ ssRNA & Filamentous & Aphid \\
\hline & & American hop latent virus (AHLV) & & & \\
\hline & & Hop latent virus (HpLV) & & & \\
\hline \multirow[t]{3}{*}{ Secoviridae } & Nepovirus & Arabis mosaic virus (ArMV) & $(+)$ ssRNA & Isometric & Dagger nematode \\
\hline & & Tobacco ringspot virus (TRSV) & & & \\
\hline & & Tomato ringspot virus (ToRSV) & & & \\
\hline \multirow[t]{4}{*}{ Pospiviroidae } & Apscaviroid & Apple fruit crinkle viroid (AFCVd) & ssRNA & N/A & Mechanical \\
\hline & Cocadviroid & Citrus bark cracking viroid (CBCVd) & ssRNA & N/A & Unknown \\
\hline & & Hop latent viroid (HLVd) & & & Seed \\
\hline & Hostuviroid & Hop stunt viroid (HSVd) & ssRNA & N/A & Mechanical \\
\hline Acholeplasmataceae & Phytoplasma & Candidatus Phytoplasma asteris & dsRNA & N/A & Leafhoppers \\
\hline \multicolumn{6}{|l|}{ NCPN-Roses } \\
\hline \multirow[t]{3}{*}{ Bromoviridae } & Ilarvirus & Apple mosaic virus (ApMV) & $(+)$ ssRNA & Quasi-isometric & Pollen \\
\hline & & Prunus necrotic ringspot virus (PNRSV) & & & \\
\hline & & Blackberry chlorotic ringspot virus (BCRV) & & & \\
\hline Caulimoviridae & Rosadnavirus & Rose yellow vein virus (RYVV) & dsDNA & Bacilliform & Unknown \\
\hline Fimoviridae & Emaravirus & Rose rosette virus (RVV) & $(-)$ RNA & Isometric & Mite \\
\hline Luteoviridae & Luteovirus & Rose spring dwarf-associated virus (RSDaV) & $(+)$ RNA & Isometric & Aphids \\
\hline \multicolumn{6}{|l|}{$\begin{array}{l}\text { NCPN- } \\
\text { Sweetpotatoes }\end{array}$} \\
\hline Closteroviridae & Crinivirus & Sweet potato chlorotic stunt virus (SPCSV) & $(+)$ ssRNA & Filamentous & Whiteflies \\
\hline Geminiviridae & Begomovirus & Sweet potato leaf curl virus (SPLCV) & ssDNA & Twinned & Whiteflies, seed \\
\hline \multirow[t]{4}{*}{ Potyviridae } & Potyvirus & Sweet potato feathery mottle virus (SPFMV) & $(+)$ ssRNA & Filamentous & Aphids \\
\hline & & Sweet potato virus G (SPVG) & & & \\
\hline & & Sweet potato virus C (SPVC) & & & \\
\hline & & Sweet potato virus 2 (SPV2) & & & \\
\hline
\end{tabular}


In wine grapes, grapevine leafroll disease causes losses ranging from $\$ 25,000$ to over $\$ 226,000$ per hectare over a predicted 25 -year lifespan of a vineyard, depending on disease prevalence, level of yield reduction, price penalty for suboptimal fruit quality and the grape growing region (Atallah et al. 2012; Ricketts et al. 2015). Similarly, losses to grapevine red blotch disease were estimated to range from $\$ 2,200$ per hectare in eastern Washington state to over $\$ 69,500$ per hectare in Napa County, California over a predicted 25-year life span of a vineyard (Ricketts et al. 2017). The annual impact of grapevine leafroll-associated virus 3 (GLRaV-3), the major virus associated with leafroll disease (Almeida et al. 2013), is estimated at $\$ 90$ million in California (Cheon et al. 2020). For Pierce's disease, the economic fallout to the grape and wine industry in California is similarly estimated at $\$ 92$ million annually (Alston et al. 2013).

In fruit trees, the discovery of plum pox virus (PPV) in Pennsylvania in 1999 resulted in enactment of a statewide eradication program. This is because PPV is a regulated invasive species in the United States. The cost of the PPV eradication program in Pennsylvania was \$59 million from 1999 to 2009 in USDA and Pennsylvania Department of Agriculture payouts (Welliver et al. 2014). In addition, close to 810 hectares of stone fruit orchards and over 2,500 trees in garden centers, landscape nurseries and homeowner properties were removed and destroyed (Welliver et al. 2014). A more recent example of the economic impact of a fruit tree disease is the dual epidemic of little cherry virus 2 (LChV2), the major causal agent of little cherry disease (Harper et al. 2019a), and Candidatus phytoplasma pruni, the causal agent of X-disease (Harper et al. 2019b), which is projected to reduce cherry production in the Pacific Northwest of the United States by $12 \%$ in 2020 . To date, over 400 hectares of sweet cherry trees and close to 300 hectares of other stone fruit trees have been removed to contain the two pathogens and reduce their spread (Mejica 2020; Prengaman and Mullinax 2019).
With documented losses in the billions of dollars annually, economic studies stress how costly select diseases of specialty crops can be in the United States (Yeh et al. 2019). Economic studies also underscore how destabilizing diseases like HLB or plum pox can be to growers' communities with employment losses, interruptions in production, diversification of farm operations, relocations of production fields and nurseries or confinements of nursery operations (Singerman 2019; Welliver et al. 2014). Similarly, actions promoted by governmental agencies to avoid crop losses due to diseases of specialty crops through certification, eradication or quarantine programs are costly (Singerman 2019; McRoberts et al. 2019; Olexa and Benn 2018; USDA-NASS 2020; Welliver et al. 2014).

\section{Pathogen-Tested, Foundation Plant Stocks of Specialty Crops and the NCPN}

The management of diseases caused by graft-transmissible pathogens of specialty crops is essentially prophylactic with the production and maintenance of pathogen-tested (negative) foundation plant stocks, and the distribution of propagation material derived thereof to nurseries and growers for the generation of clean planting material or of producing plants (Gergerich et al. 2015). Clean, pathogen-tested foundation plant stocks are the backbone of sustainable specialty crop production. The production, maintenance, and distribution of pathogen-tested foundation propagative material, i.e., scion budwood, rootstock cuttings, liners, seedlings, or rhizomes, is essential for the production of plants for planting that are healthy and of high horticultural quality. One can think of investments in pathogen-tested foundation plant stocks and their distribution to growers as an insurance policy to avoid future economic losses.

In the United States, the production, maintenance, and distribution of pathogen-tested foundation propagation material is supported by

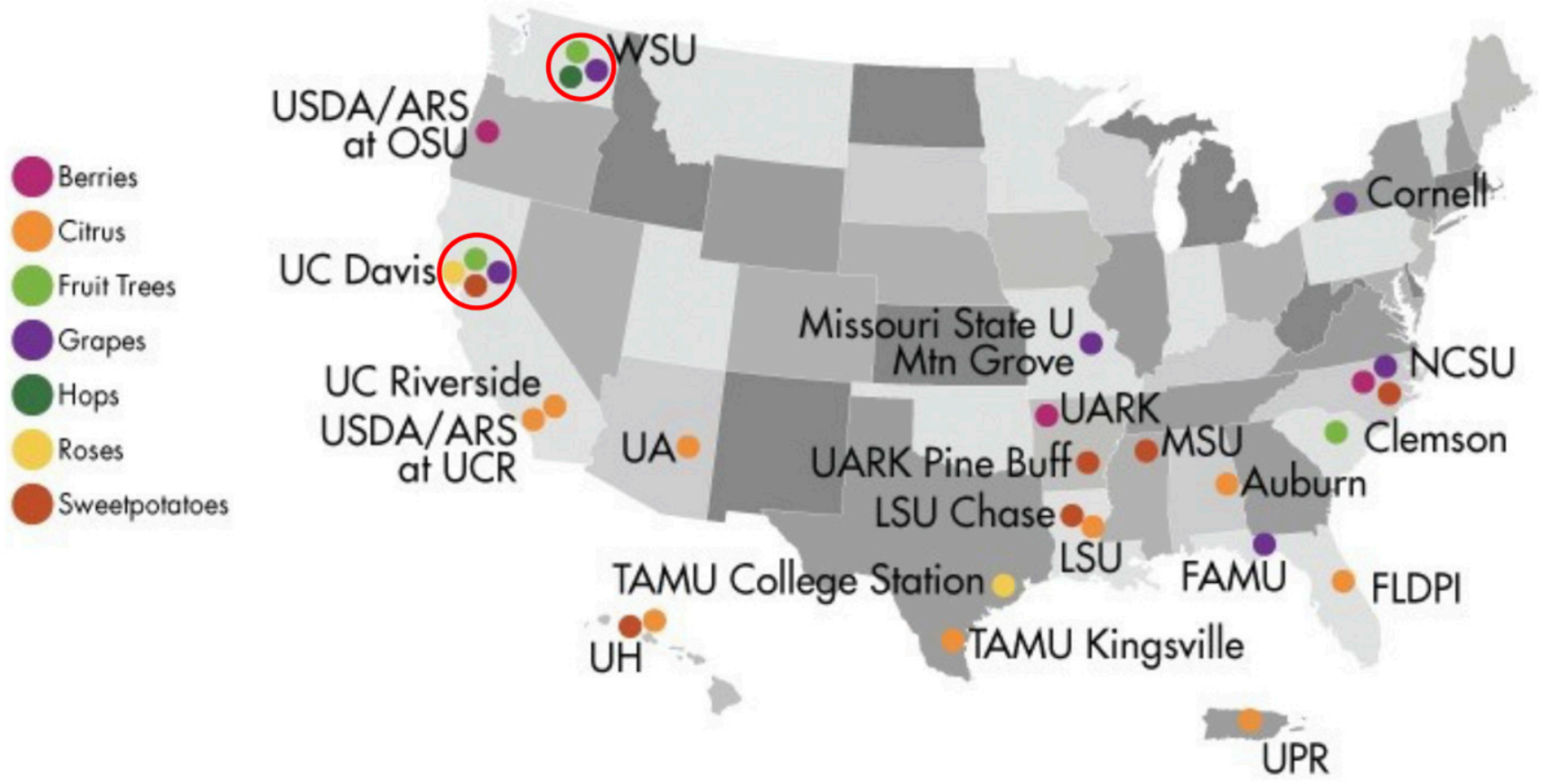

Fig. 1. Centers of the National Clean Plant Network (NCPN) that produce and maintain pathogen-tested foundation stocks in the United States, and distribute material derived thereof, as of 2020. From left to right: Foundation Plant Services, University of California - Davis (UC Davis) in Davis, CA; United States Department of Agriculture-Agriculture Research Service (USDA-ARS) at Oregon State University (OSU) in Corvallis, OR; University of California - Riverside (UC Riverside) and USDA-ARS, National Clonal Germplasm Repository for Citrus and Dates in Riverside, CA; Washington State University (WSU) in Prosser, WA; University of Hawaii (UH) in Honolulu, Hl; University of Arizona (UA) in Yuma, AZ; Texas A\&M University (TAMU) in Kingsville, TX; Texas A\&M University (TAMU College Station) in College Station, TX; University of Arkansas (UARK) in Fayetteville, AR; Louisiana State University (LSU) in Chase, LA; University of Arkansas (UARK Pine Bluff) Division of Agriculture in Pine Bluff, AR; Louisiana State University (LSU) in Baton Rouge, LA; Missouri State University (Missouri State Mtn Grove) in Mountain Grove, MO; Mississippi State University (MSU) in Pontotoc, MS; Auburn University (Auburn) in Auburn, AL; University of Puerto Rico (UPR) in Mayaguez, PR; Florida A\&M University (FAMU) in Tallahassee, FL; Florida Department of Agriculture and Consumer Services, Division of Plant Industry (FLDPI) in Winter Haven, FL; Clemson University (Clemson) in Clemson, SC; Florida Department of Agriculture and Consumer Services, Division of Plant Industry (FLDPI) in Winter Haven, FL; Cornell University (Cornell) in Geneva, NY; and North Carolina State University (NCSU) in Raleigh, NC. The specialty crops managed at each NCPN center are indicated by colored dots. Research on economic benefits focused so far on the two NCPN centers circled in red. 
the NCPN, which was created to protect specialty crops from economically harmful plant pests and diseases (NCPN 2020a). The NCPN is managed by the USDA's Animal and Plant Health Inspection Service (APHIS) in conjunction with USDA's Agriculture Research Service, and USDA's National Institute for Food and Agriculture (NCPN 2020a). The mission of NCPN centers is to produce and maintain pathogen-tested foundation plant stocks, and distribute clean propagative material derived thereof to nurseries, growers, and consumers (Gergerich et al. 2015). To date, the NCPN comprises seven crop-specific networks, i.e., grapes, fruit trees, citrus, berries, hops, roses, and sweetpotatoes. These seven networks consist of 33 clean plant centers located in 20 states and one territory (NCPN 2020b). Among the 33 clean plant centers affiliated with the NCPN, 22 are involved in the production and maintenance of pathogen-tested foundation stocks and the distribution of materials derived thereof. They are located in 16 states, i.e., Alabama, Arizona, Arkansas, California, Florida, Hawaii, Louisiana, Maryland, Missouri, Mississippi, North Carolina, New York, Oregon, South Carolina, Texas, and Washington, and one territory, i.e., Puerto Rico (Fig. 1). Most clean plant centers are involved in a single crop-specific network and a few are involved in multiple crop-specific networks (Fig. 1).

Pathogen-tested foundation plant stocks are primarily maintained in foundation sites referred to as G1 blocks (Fig. 2). Only a limited number of plants (usually less than five) are routinely kept for each clean accession (i.e., cultivar, clone, genotype, selection, etc.) in G1 foundation blocks. Plant material in G1 blocks is kept in open sites, as well as enclosed settings, i.e., greenhouses, screenhouses, plastic houses, and/or tissue culture growth rooms (Fig. 3). Material from G1 blocks is then established in increase fields, referred to as G2 blocks, to bulk up the number of propagative units needed for the production of planting material to be sold to growers. Material from G2 blocks can be further propagated and established in G3 blocks, and eventually in G4 blocks (Fig. 2).

Material in G1 blocks is established and maintained by NCPN centers as registered foundation stock with a state department of agriculture (Fig. 2). Material in G2 to G4 blocks is typically established and maintained by nurseries and registered and/or certified by their respective state department of agriculture (Fig. 2). Registration and certification are essential to ascertain the health of G1 to G4 plants with regard to the absence of detrimental diseases for which assays are available to test for causal or associated agents, and to minimize the introduction of regulated diseases and pests in G1 to G4 blocks (Gergerich et al. 2015). These processes are also essential to ensure the health of planting material. Although we recognize the utmost importance of registration and certification programs for managing graft-transmissible pathogens of specialty crops, we will not further discuss them in this article.

Selected pathogens of importance to NCPN centers are listed in Table 1. For a complete list of pathogens dealt with by NCPN centers, visit http://nationalcleanplantnetwork.org/. Nearly every pathogen managed by NCPN centers is graft transmissible. Plant stocks at various G1 foundation blocks that test negative for these pathogens are maintained by NCPN centers. These include thousands of accessions for most crops: 2,250 fruit trees, 1,000 grapevines, 1,000 citrus, close to 300 berries, 170 sweetpotatoes, 50 hops, and 600 roses (NCPN 2020c). In addition, NCPN centers distribute annually to nurseries and growers approximately 100,000 units of propagation material (cuttings, scions, and plantlets) and more than 340,000 buds of fruit trees; 140,000 cuttings, buds, plants, and seeds of grapevines; material for the annual production of 30 million clean berry plants; material for the production of 7.5 million clean citrus trees; 1,000 propagative units of hops; 100,000 sweetpotato plants; and more than 80,000 propagative units of roses (NCPN 2020c).

\section{Management of Pathogen-Tested Foundation Plant Stocks at NCPN Centers}

The establishment and maintenance of G1 blocks by NCPN centers is laborious and costly. Traditionally, G1 blocks of pathogentested plant stocks were in open settings (Fig. 3). These conditions can compromise the health of G1 plants via the introduction of pathogens via pollen- or vector-mediated transmission. This reality called for rigorous approaches to mitigate the influx of pathogens via aerial dispersal of viruliferous vectors or infected pollen and the use of best practices to maintain the health of precious plant materials in G1 blocks. To minimize exposure to secondary spread of pathogens from nearby virus sources, isolation of G1 field sites from similar plants or cross-compatible plant species is used. Nonetheless, extensive monitoring and testing of G1 fields is required annually when established in the open. Any infected plant needs to be immediately removed with systematic follow-up to ensure that no secondary spread has occurred within the foundation block. An elegant approach to minimize the consequences of aerially dispersing vectors or pollen movement from undesired plant sources is to establish and maintain pathogen-tested stocks in greenhouses or screenhouses with pest exclusion features (Fig. 3). This approach was adopted early by the citrus industry as a consequence of HLB outbreaks (USDA-APHIS 2020; Vidalakis et al. 2014), then by the tree fruit industry in the Pacific northwestern United States in response to the vector-borne $\mathrm{Ca}$. phytoplasma pruni in Prunus spp. (Harper et al. 2019b), and more recently by the grape industry in California in response to the discovery of red blotch disease in foundation vineyards (Farrar 2019). Another approach to avoid plant exposure to detrimental pathogens is to maintain and propagate pathogen-tested foundation stocks in tissue culture containers. This strategy was implemented by the berry industry (Fig. 3). Maintaining G1 blocks in screened greenhouses, screenhouses, and/or tissue culture vessels sustains the cleanliness of foundation plant stocks over time.

The supply of pathogen-tested stocks can occasionally fall short of grower demand (Hansen 2014; Herrick 2014; Weinstock 2016). For example, growers can request cultivars, particularly new cultivars or new clones of existing cultivars, in substantial quantity and at a certain time to diversify their production. These cultivars or clones might not be available, or their availability might be limited in G1 blocks. A high demand for new cultivars or new clones and the drive to get them into the marketplace quickly often forces nurseries to produce planting material derived from stocks that are not tested for pathogens. This is particularly true for apple production, for which there is a constant turnover of cultivars in orchards in response to market demands and to the industry transitioning to high density plantings (Herrick 2014; Weinstock 2016). As a consequence, pathogens can be introduced into production fields via unchecked planting material, potentially starting new epidemics and incurring substantially increased management costs. An example of this is the discovery of little cherry virus 1 spreading by root-grafting though a cherry orchard in central Washington State; as this virus lacks a vector (Fuchs et al. 2020), it could only have been introduced through infected planting material (Harper, unpublished). To facilitate the timely availability of new materials that are tested for pathogens, breeding programs are encouraged to screen their elite selections for pathogens at NCPN centers when launching new cultivars or new clones. This ensures that pathogen-tested source materials are available at nurseries for the timely production of clean planting material in the amount needed to supply the demand.

\section{Economic Benefits of NCPN Centers}

A literature review recently summarized the economic benefits of NCPN centers (Yeh et al. 2019). To date, these studies have focused on two centers: Clean Plant Center Northwest (CPCNW), Washington State University in Prosser, WA; and Foundation Plant Services (FPS), University of California in Davis, CA (Fig. 1). The economic benefits of the center in Prosser, WA, were estimated based on projected yield losses and quality decline due to viruses in fruit trees such as apples, sweet cherries, and clingstone peaches. The total gross annual benefit to fruit tree growers and nurseries was close to $\$ 81$ million annually or 150 times the cost of establishing and operating the center (Cembali et al. 2003). These findings suggested that for every dollar invested in the clean plant center in Prosser, $\mathrm{WA}$, there is a $\$ 150$ return to the fruit tree growers and nurseries. The return for consumers (\$147 million) was approximately 270fold. These benefits were primarily calculated in terms of avoiding higher retail prices and higher production costs due to virus diseases. 
They were estimated based on the performance of the fruit tree industry, assuming it is entirely virus free (Cembali et al. 2003). Notably, this assumption is unrealistic, given the documented foray of pathogens in production orchards via aerial vectors. Therefore, the benefits to consumers might have been overvalued in this study. For the same center, an earlier analysis estimated returns of $\$ 2.6$ billion over 20 years to apple, cherry, pear, and peach growers in the Pacific Northwest of the United States (Seavert and Julian 2012). These two
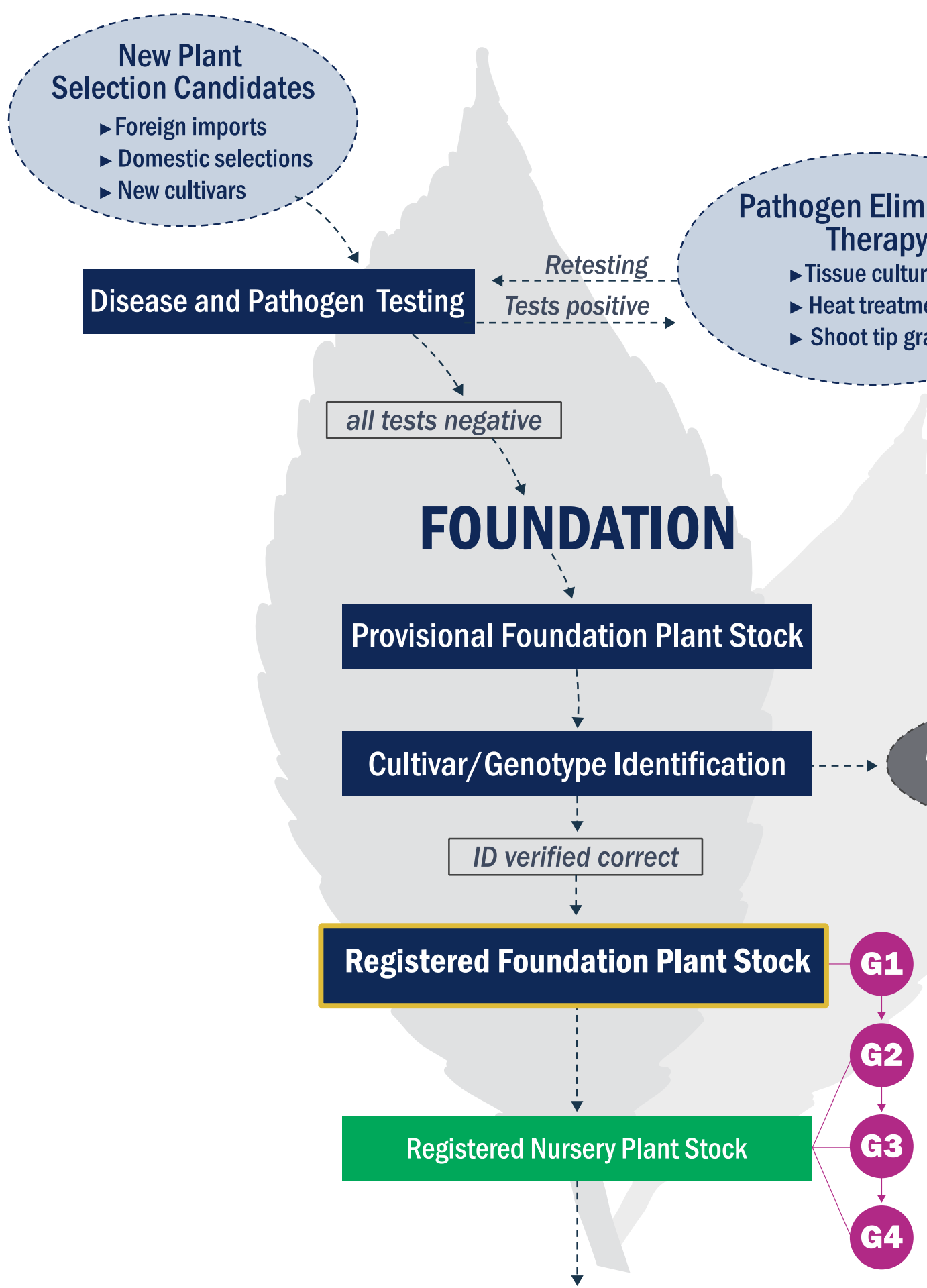

\section{Certified Planting Material for Growers}

Fig. 2. Flowchart depicting the journey of a specialty crop selection through a center of the National Clean Plant Network (NCPN). Plant selection candidates are introduced from foreign or domestic sources and extensively tested for pathogens and diseases. If tests are positive, plant selection candidates may be sanitized using appropriate therapeutic methodologies and, following treatment, tested again to verify that the pathogen(s) of concern has been eliminated. If tests are negative, the identity of the plant selection candidates may be tested by morphological characteristics or DNA fingerprinting. If the selection is correctly identified, it qualifies as a foundation plant stock for establishment in a $\mathrm{G} 1$ block and registration by a state department of agriculture. Plant material from $\mathrm{G} 1$ blocks is then established by nurseries in increase blocks referred to as $\mathrm{G} 2$ blocks. Material from $\mathrm{G} 2$ blocks can be further propagated by nurseries and established in G3 blocks, and subsequently in G4 blocks. Plant material in G2 and G3 blocks is registered by a state department of agriculture and provides the planting material that is certified by a state department of agriculture and made available to growers. For berries, nurseries sell G2 or G3 tissue cultured plants to growers. NCPN activities are depicted in blue on the flowchart. 
seminal studies were the first to document the economic impact of a clean plant center in the United States.

More recently, an economic analysis of FPS, the major NCPN center for grapes, was performed as a collaborative effort between agriculture economists, center leaders, nursery managers, state regulators, extension educators, and vineyard managers. The analysis of the costs and benefits of testing for GLRaV-3 at FPS documented benefits exceeding \$20 million annually for the north coast of California, with economic returns outweighing costs 10-fold (Fuller et al. 2019). For the rest of the main grape growing regions in California, the annual value of the same program was estimated at $\$ 70$ million (Cheon et al. 2020). Combined, the value of GLRaV-3 screening in California is estimated at $\$ 90$ million per year or approximately $1.6 \%$ of the estimated $\$ 5.5$ billion value of the grape industry in California (Cheon et al. 2020). Another study estimated the economic impacts of public investments in FPS by focusing on grapevine leafroll disease. It revealed returns to public investments ranging from a 19:1 to a 99:1 ratio with a $5 \%$ and a $20 \%$ disease infection rate in commercial vineyards, respectively, from 2006 to 2015 (Gómez, unpublished data). Projections to the next 10 years indicated returns to public investments ranging from a $38: 1$ to a $140: 1$ ratio with a $5 \%$ and a $20 \%$ disease infection rate in vineyards (in 2015-dollar value) by 2025 . These findings stressed the tremendous economic impact of an NCPN center. In addition, Gómez and colleagues analyzed how resources are allocated regarding the production and adoption of clean planting material. These authors suggested that grape growers and nurseries reap most of the benefits of clean planting material derived from virus-tested G1 stocks, as opposed to wineries, because the grape supply is less responsive to prices relative to the wine industry demand for grapes.

In summary, economic studies highlighted the critical nature of NCPN centers for the sustainability of viticulture and fruit tree production with documented returns on public investments ranging from 10:1 to $150: 1$. With positive industry returns largely exceeding total costs, the cost-effectiveness of these two clean plant centers is undeniable. In addition, economic studies revealed that growers and nurseries receive the primary benefits of clean planting material derived from pathogen-tested foundation plant stocks. It should be noted that CPCNW, FPS, and most NCPN centers do not rely exclusively on public resources to operate. They primarily use funds provided by growers and nurseries through user fees for the purchase and propagation of propagative material sourced from G1 plant stocks or through commodity marketing orders or checkoff programs. They also rely to some extent on institutional support (e.g., use of land grant university resources such as human and physical capital) to operate and fulfill their mission. However, public funds are critical for continuous operations of NCPN centers, regardless of how markets fluctuate.

\section{Disease Management Options That Minimize the Negative Impacts of Graft-Transmissible Pathogens on Grower Profits}

Once in the field, diseases of specialty crops caused by graft-transmissible pathogens require expensive management strategies at the local, regional, or national level. Reduction or elimination of pathogens are the primary objectives of disease management solutions in the field. These are primarily achieved by roguing in combination with insect vector control strategies, if applicable and appropriate, and entire field removals (Sisterson and Stenger 2013). These strategies are designed to reduce or eliminate the pathogen inoculum and to limit disease spread.

Roguing and orchard removals have recently been applied to manage simultaneous outbreaks of LChV2 and $C a$. phytoplasma pruni in cherry orchards in the Pacific Northwest of the United States (Mejica 2020; Prengaman and Mullinax 2019). Similarly, virus disease management in vineyards relies on extensive scouting, roguing, or elimination of entire parcels and, if appropriate, applications of agrochemicals to control vector populations, particularly mealybugs, soft scale insects, and dagger nematodes (Almeida et al. 2013; Bell et al. 2018; Maliogka et al. 2015; Pietersen et al. 2017). Multiyear
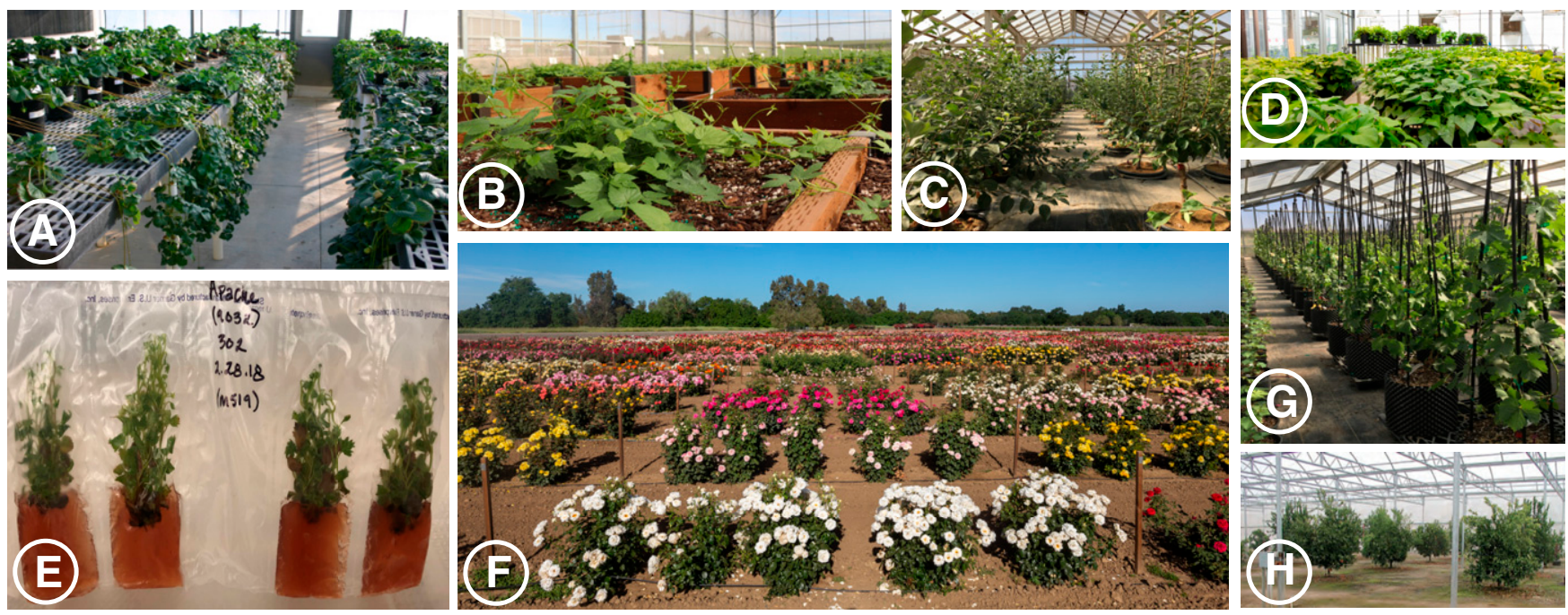

Fig. 3. Pathogen-tested foundation $\mathrm{G} 1$ specialty crop plant stocks maintained in open fields, enclosed settings with pest exclusion features, and tissue culture containers at centers of the National Clean Plant Network (NCPN). A, G1 strawberry plants maintained in greenhouses with pest exclusion features at Foundation Plant Services (FPS), University of California-Davis in Davis, CA, with annual screening for viruses and DNA fingerprinting to ensure no propagation or labeling errors are made. B, G1 hops maintained in a greenhouse with pest exclusion features at the Clean Plant Center Northwest (CPCNW), Washington State University, in Prosser, WA. C, G1 apple trees in a greenhouse at the CPCNW, Washington State University, Prosser, WA. D, G1 sweetpotato plants maintained in a greenhouse with double door entries and strict vector control procedures at FPS, University of California-Davis in Davis, CA, because damaging viruses are readily transmitted by aphids and whiteflies. E, G1 blackberry plantlets maintained in gas permeable polyethylene Star*Pac bags in a tissue culture growth room and then in a cold storage room for 2.5 years with extensive indexing for viruses and DNA fingerprinting at USDA-ARS in Corvallis, OR. F, G1 roses maintained at FPS, University of California-Davis, Davis, CA, in field plantings with annual screening for prunus necrotic ringspot virus and apple mosaic virus. With the support of NCPN, the collection, which was established in the 1960s, was repropagated and expanded in recent years to include over 800 scion selections and eight rootstock genotypes. G, G1 grapevines maintained in a greenhouse with pest exclusion features at the CPCNW, Washington State University, in Prosser, WA. H, G1 citrus budwood source trees maintained in 80,000 sq. ft. screenhouse structures with pest exclusion features since 1998 and backed up twice in two compartments of a 5,700 sq. ft. positive pressure greenhouse, built by the citrus industry at the Lindcove Research and Extension Center, University of California-Agriculture and Natural Resources, in Exeter, CA. Pathogen tested citrus germplasm is also cryopreserved at the USDA-ARS, National Center for Genetic Resources Preservation at Fort Collins, CO. 
studies on the spatiotemporal dynamics of leafroll disease in California (Cooper et al. 2018), New Zealand (Bell et al. 2018), and South Africa (Pietersen et al. 2013) vineyards substantiated that leafroll disease management should target both mealybug vectors via population suppression approaches and virus inoculum via the removal of diseased vines. These solutions have been successfully adopted for the management of leafroll disease in South Africa and New Zealand (Pietersen et al. 2017). Interestingly, economic studies confirmed the merit of roguing in combination with insecticide applications to reduce mealybug populations when leafroll disease prevalence is low (between 5 and 10\%), whereas a full vineyard replacement should be pursued if disease prevalence is higher, generally above $25 \%$, although regional differences were clearly noted among the three studied grape-growing regions in California (Ricketts et al. 2015). Other studies reached similar conclusions in New York (Atallah et al. 2012), New Zealand (Bell et al. 2018; Pietersen et al. 2017), South Africa (Pietersen et al. 2013, 2017), and the north coast of California (Fuller et al. 2019). Economical leafroll disease management recommendations should be considered as general guidelines that need to be customized at a parcel, estate, or regional scale. This is because singularities among estates and grape-growing regions in terms of vineyard management practices, tolerance to the effects of leafroll disease on fruit quality, and business model need to be captured for the development of tailored solutions.

For grapevine red blotch disease, management strategies consist of roguing and removal of entire vineyard parcels without the application of insecticides (Cieniewicz et al. 2019b). Populations of the three-cornered alfalfa hopper (Spissistilus festinus, Say, 1830) vector of GRBV (Bahder et al. 2016) are low in vineyards; they visit vineyards predominantly during a short period of the growing season (Cieniewicz et al. 2017, 2019a) and do not reproduce on grapevines (Preto et al. 2018). Thus, controlling vector populations is not recommended to mitigate the impacts of red blotch disease. Roguing symptomatic vines and selecting replants derived from virus-tested foundation vine stocks are predicted to minimize economic losses if the incidence of red blotch disease is low to moderate (below $30 \%$ ), whereas a full vineyard replacement should be pursued if disease incidence is higher, generally above $30 \%$ (Ricketts et al. 2017). Again, strategies designed to minimize the negative impacts of grafttransmissible diseases on grower profits should be considered as guidelines to develop customized actions at a parcel, estate, or regional scale.

In citrus, disease management solutions are drastic, essentially due to the severity of HLB. Areas affected by HLB are quarantined to limit the spread of the disease; eradication programs are instituted to remove infected trees to protect the citrus industry. In addition, the movement of citrus fruits and propagative materials is regulated; only cleaned or packed fruits are allowed to move in order to minimize the dissemination of psyllids. Also, only materials derived from pathogen-tested plant stocks are used to replant groves or replace trees infected with HLB or other pathogens (CDFA 2019; McRoberts et al. 2019; Morris and Muraro 2008; Roka et al. 2009; Salifu et al. 2012). Furthermore, nurseries are required to produce trees under insect exclusionary structures, such as screenhouses or greenhouses. Transportation of citrus nursery stock is allowed after treatment with approved insecticides and only achieved in enclosed vehicles. In citrus groves, frequent agrochemical treatments of trees are mandated for the control of psyllid vectors to reduce disease spread. Most importantly, coordinated area-wide management of psyllid vectors by multiple growers with applications timed only a few days apart has been adopted to reduce psyllid populations and the spread of HLB. This practice is economically more attractive and biologically more effective than actions taken by individual growers (CDFA 2019; McRoberts et al. 2019; Olexa and Benn 2018; Sherman et al. 2019; Singerman et al. 2017).

In summary, economic studies made substantial contributions to minimize the economic impacts of graft-transmissible pathogens of specialty crops once diseases are present in growers' fields (Atallah et al. 2012; Bell et al. 2018; Cieniewicz et al. 2019b; Fuller et al. 2019; Pietersen et al. 2017; Ricketts et al. 2015, 2017). Additionally, economic assessments provided evidence that preventive actions to ensure clean planting material are more beneficial to the specialty crop sector relative to farm-level management strategies (Alston et al. 2013; Cembali et al. 2003; Seavert and Julian 2012).

\section{Economic Studies Contribute Integrated Disease Management Solutions That Resonate With Growers}

Disease management recommendations based on roguing and parcel removal and/or control of vector populations are routinely communicated to growers of specialty crops by plant pathologists and extension educators. However, these recommendations can be imperceptible to grower communities. This is because a message rooted only in disease ecology does not always resonate with a grower audience. Consequently, growers can be reluctant to practice roguing or parcel removals because they perceive limited, if any, financial gain.

Although disease ecology informs disease management (Jones and Naidu 2019; Sisterson and Stenger 2013), economic studies provide additional guidance for a strategic selection of optimal solutions. For example, as discussed above, roguing is recommended when the incidence of grapevine red blotch disease in a vineyard is below $30 \%$ and parcel removal is recommended when disease incidence is above $30 \%$ (Ricketts et al. 2017); and no action is recommended against the treehopper vector of GRBV (Cieniewicz et al. 2019b). In other words, economic losses are minimized if growers practice roguing when disease incidence is low to moderate, whereas a full vineyard removal should be pursued if disease incidence is higher, generally above 30\% (Ricketts et al. 2017). The consideration of a disease threshold (30\% in the case of red blotch) provides growers with a tangible indicator to take action. Additionally, decision matrices developed by agriculture economists are highly valuable to select optimal disease management options. Such decision matrices can tailor management recommendations by taking into account various factors such as production costs at a regional level, infection prevalence at the parcel level, disease onset, yield reduction, and price penalty for poor fruit quality. This tailored approach was used to formulate management recommendations for grapevine leafroll disease in New York (Atallah et al. 2012) and California (Ricketts et al. 2015). In California's Napa County, roguing is recommended when the disease infection rate is $20 \%$, disease onset is late (12 years postplanting), and production is reduced by $25 \%$. In the Northern San Joaquin Valley of California, vineyard replacement is recommended under the same scenario. In contrast, the recommendation for Sonoma County growers in California is to opt for no action as an economically optimal strategy (Ricketts et al. 2015). Similar decision matrices are available for grapevine red blotch disease (Ricketts et al. 2017). Decision matrices provide valuable action roadmaps for growers to consider by offering tailored disease management solutions regionally and at an estate level.

An integrated approach to disease management that is rooted in disease ecology and based on profit-maximizing solutions is more palatable to growers compared with options rooted only in disease ecology, as monetary incentives speak volumes to producers. Consequently, integrated disease management recommendations often resonate with growers because they perceive opportunities for returns on their investment compared with taking no action. In turn, planting materials derived from $\mathrm{G} 1$ plant stocks are more readily used by growers to replace plants that have been eliminated through roguing and parcel removals, as illustrated by recent actions taken by numerous grape growers in California to combat leafroll and red blotch diseases in vineyards.

\section{Future Economic Research}

While the studies described above addressed the economic benefits of clean planting materials for specific crops and the costs of select diseases, many of the specialty crops supported by the NCPN have not been the subject of rigorous studies to fully understand the benefits of ensuring clean planting material. Economic studies have estimated the economic impacts of select diseases of a limited number of specialty crops and assessed the value of just a couple of NCPN centers. In spite of their small number, economic studies have 
been highly valuable for the NCPN. Their findings provided a compelling justification for public investments in NCPN centers with benefits largely outweighing costs by conservative estimates ranging from 10:1 to 150:1. Economic studies also incentivized the adoption of clean planting material derived from pathogen-tested G1 stocks in support of sustainable specialty crop production. They further contributed to the development of disease management solutions that are rooted in profit maximization, as well as ecologically driven options. Finally, they have facilitated the crafting and dissemination of information on disease management strategies that resonate with growers. This latter outcome has transformed the ability of plant pathologists to deliver a palatable and impactful message on the control of detrimental diseases in the field. The delivery of disease control recommendations that speak to growers, particularly on how they relate to the financial management of their field operations and estates, rather than ivory tower-rooted recommendations is much more inspirational and convincing. This change in communication strategy has generated new opportunities for long-term collaborative interactions with growers and for a higher adoption rate of clean planting material derived from G1 stocks (M. Fuchs, personal observations).

There is an urgent need for additional economic studies to document the value of the NCPN. Research on berries, hops, citrus, roses, and sweetpotatoes is particularly needed, as either no or limited information is available on the economic impact of diseases or benefits of clean plant centers. New studies should first examine the costs of production during the lifecycle of the crop and determine the economic impacts of key diseases. This type of information allows the foundation to address disease management solutions and to identify economical and effective options under different scenarios. Similarly, new research efforts could refine existing data for fruit trees and grapes, as well as address pending issues related to different producing regions and to new diseases. For example, studies on grapevine red blotch disease could complement previous studies on grapevine leafroll disease and cover grape-growing areas other than northern California, eastern Washington, and New York. Also, economic studies on fruit tree diseases that were carried out almost 10 years ago (Cembali et al. 2003; Seavert and Julian 2012) should be refreshed. Furthermore, new economic studies could complement past investigations that narrowly focused on a single specialty crop, e.g., grapes at FPS in Davis, CA, and fruit trees at the CPCNW in Prosser, WA, by assessing their value to other specialty crops that are handled by these two NCPN centers. In addition, they could also assess the returns on investment in a specific specialty crop network of clean plant centers. For example, studies could focus on the economic value of all the NCPN-Citrus centers or all the NCPN-Berries centers to estimate the returns for citrus and berries, respectively.

Economic studies have traditionally focused on a single pathogen (Fuller et al. 2019) or a single disease (Gómez, unpublished data) to estimate the value of NCPN centers. Such estimates are restrictive and may have underestimated contributions of the centers, as infections by multiple pathogens are common in the field for specialty crops (Fuchs 2020; Gergerich et al. 2015; Maliogka et al. 2018; Martin and Tzanetakis 2018; Wright et al. 2020). Thus, most estimates substantially undervalue the economic benefits of clean plant centers. This is because the tallied combined economic impact of more than one pathogen or disease will likely be higher than the economic impact of a single pathogen or disease; in turn, the economic value of clean plant centers will be higher if multiple pathogens are considered compared with single pathogens. A more global approach that considers the costs of multiple pathogens or diseases would be desirable to better describe and capture the actual value of NCPN centers.

New economic studies could also assess the value of G1 stocks to nurseries in order to encourage the adoption of clean planting material by commercial producers. Such projects would also better describe socioeconomic factors that drive market dynamics and growers' preferences in terms of the adoption of and willingness to pay for clean planting material. These studies would also better circumscribe the rationale for a lack of price difference between planting material derived from G1 stocks and those derived from other stocks for certain specialty crops. It is anticipated that the higher net present value of planting material derived from pathogen-tested stocks should justify higher prices to the nurseries. However, more studies on grower willingness to adopt and willingness to pay are needed to identify what such a price premium is, if any, for each crop and grower group. Although not directly related to NCPN, an example of such studies is a recent survey of factors affecting the demand for clean sweetpotato planting material by smallholder farmers in Kenya (Mwiti et al. 2020). This study included only clean planting material; therefore, it remains unknown whether surveyed farmers place a price premium on clean sweetpotato, relative to untested planting material, and what factors might drive such premium.

Finally, studies should thoroughly evaluate how disease management actions of neighboring growers might increase or decrease the incentive of growers to adopt optimal profit-maximizing and ecologically driven management solutions, and to select planting material derived from G1 stocks. This would be valuable particularly in the case of airborne vectormediated spread of pathogens for which a collective, regional, or national approach to disease management is not widely adopted. Addressing socioeconomic factors that drive growers' actions to manage or not to manage diseases in the field when neighboring growers are making certain choices would provide insights that could potentially advance a wider use of clean planting stock (Sherman et al. 2019). These efforts could result in incentives for neighboring growers to cooperate and strategically coordinate disease management efforts at a larger scale, as investigated for grapevine leafroll disease (Atallah et al. 2017), HLB (McRoberts et al. 2019), the ACP vector of HLB (Fenichel et al. 2014), and a fungal disease of hops (Sherman et al. 2019). Similarly, better understanding of socioeconomic elements that drive growers' decisions to use or not to use certified planting material would eventually provide new opportunities to strategically increase the adoption of plants derived from $\mathrm{G} 1$ stocks. Finally, future research efforts should address how to best communicate findings of economic studies to growers and nurseries to foster the use of clean planting material, as elegantly documented for the adoption of integrated pest management (Sherman and Gent 2014).

\section{Conclusions}

Pathogen-tested foundation plant stocks are the cornerstone of sustainable specialty crop cultivation. The production, maintenance, and distribution of pathogen-tested propagative material are managed in the United States by clean plant centers that are affiliated with the NCPN under the aegis of USDA-APHIS. Nurseries and growers source these plant products (buds, cuttings, liners, seeds, rhizomes) to produce clean planting materials for the establishment and easier maintenance of disease-free plantings of specialty crops. Economic studies have documented the impacts of select diseases caused by graft-transmissible pathogens of some specialty crops, identified profit-maximizing disease management solutions in the field, and assessed the returns to public investment of two NCPN centers. These economic studies have proven essential to the mission of the NCPN. Additional economic studies could further reinforce efforts to produce, maintain, and distribute pathogentested propagation material, and to enhance the adoption of clean planting material derived thereof by growers. Advancing efforts by the NCPN and its clean plant centers will help to ensure the competitiveness of the United States specialty crop industries in the global market. These efforts might also contribute to environmental sustainability of specialty crop production, as less disease pressure may result in reduced needs to apply agrochemical inputs such as pesticides for arthropod and nematode vector suppression.

\section{Acknowledgments}

We are grateful to Erich Rudyj and David Prokrym, coordinators the NCPN, for recognizing the value of economic studies to reinforce the mission of the network; to Sarah Trujillo for facilitating discussions on NCPN economic studies; to Tammy Kolt for excellent administrative assistance; to the NCPN Governing Board for supporting economic initiatives; and to Val Krist, Foundation Plant Services, University of California, Davis, CA, for expert artwork. 


\section{Literature Cited}

Almeida, R. P. P., Blua, M. J., Lopes, J. R. S., and Purcell, A. H. 2005. Vector transmission of Xylella fastidiosa: applying fundamental knowledge to generate disease management strategies. Ann. Entomol. Soc. Am. 98:775-786.

Almeida, R. P. P., Daane, K. N., Bell, V. A., Blaisdell, G. K., Cooper, M. L., Herrbach, E., and Pietersen, G. 2013. Ecology and management of grapevine leafroll disease. Front. Microbiol. 4:94.

Alston, J. M., Fuller, K. B., Kaplan, J. D., and Tumber, K. P. 2013. Economic consequences of Pierce's disease and related policy in the California winegrape industry. J. Agric. Resour. Econ. 38:269-297.

Atallah, S., Gómez, M., and Conrad, J. M. 2017. Specification of spatial-dynamic externalities and implications for strategic behavior in disease control. Land Econ. 93:209-229.

Atallah, S., Gómez, M., Fuchs, M., and Martinson, T. 2012. Economic impact of grapevine leafroll disease on Vitis vinifera cv. Cabernet franc in Finger Lakes vineyards of New York. Am. J. Enol. Vitic. 63:73-79.

Babcock, A. B. 2018. Economic impact of California's citrus industry. http:// citrusresearch.org/wp-content/uploads/Economic-Contribution-of-CaliforniaCitrus-Industry21.pdf

Bahder, B., Zalom, F., Jayanth, M., and Sudarshana, M. 2016. Phylogeny of geminivirus coat protein sequences and digital PCR aid in identifying Spissistilus festinus (Say) as a vector of Grapevine red blotch-associated virus. Phytopathology 106:1223-1230.

Barbosa, C. J., Pina, J. A., Pérez-Panadés, J., Bernad, L., Serra, P., Navarro, L., and Duran-Vila, N. 2005. Mechanical transmission of citrus viroids. Plant Dis. 89: 749-754.

Bell, V. A., Hedderley, D. I., Pietersen, G., and Lester, P. J. 2018. Vineyard-wide control of grapevine leafroll-associated virus 3 requires an integrated response. J. Plant Pathol. 100:399-408.

Bhiwani, S. S., and Razdan, M. K. 1996. Clonal propagation. Pages 483-536 in: Plant Tissue Culture: Theory and Practice. S. S. Bhiwani and M. K. Razdan, eds. Elsevier Science Publishers, Amsterdam, the Netherlands.

California Department of Food and Agriculture. 2019. Action Plan for Asian Citrus Psyllid and Huanglongbing (Citrus Greening) in California. https://www. cdfa.ca.gov/citruscommittee/docs/ActionPlan.pdf

Castle, W. S. 1995. Rootstocks as a fruit quality factor in citrus and deciduous tree crops. N. Z. J. Crop Hortic. Sci. 23:383-394.

Cembali, T., Folwell, R. J., Wandschneider, P., Eastwell, K. C., and Howell, W. E. 2003. Economic implications of a virus prevention program in deciduous tree fruits in the U.S. Crop Prot. 22:1149-1156.

Cheon, J. Y., Fenton, M., Gjerdseth, E., Wang, Q., Gao, S., Krovetz, H., Lu, L., Shim, L., Williams, N., and Lybbert, T. J. 2020. Heterogeneous benefits of virus screening for grapevines in California. Am. J. Enol. Vitic. 71:231-241.

Cieniewicz, E., Flasco, M., Brunelli, M., Onwumelu, A., Wise, A., and Fuchs, M. F. 2019a. Differential spread of grapevine red blotch virus in California and New York vineyards. Phytobiomes J. 3:203-211.

Cieniewicz, E., Pethybridge, S., Gorny, A., Madden, L., Perry, K. L., McLane, H., and Fuchs, M. 2017. Spatiotemporal spread of grapevine red blotch-associated virus in a California vineyard. Virus Res. 230:59-62.

Cieniewicz, E., Wise, A., Smith, R., Cooper, M., Martinson, T., and Fuchs, M. 2019b. Studies on red blotch ecology inform disease management recommendations. Wine Business Monthly March:92-102.

Clark, C. A., Davis, J. A., Abad, J. A., Cuellar, W. J., Fuentes, S., Kreuze, J. F., Gibson, R. W., Mukasa, S. B., Tugume, A. K., Tairo, F., and Valkonen, J. P. T. 2012. Sweetpotato viruses: 15 years of progress on understanding and managing complex diseases. Plant Dis. 96:168-185.

Clark, C. A., Ferrin, D. M., Smith, T. P., and Holmes, G. J., eds. 2013. Compendium of Sweetpotato Diseases, Pests, and Disorders, 2nd Ed. APS Press, St. Paul, MN.

Cooper, M. L., Daugherty, M. P., Jeske, D. R., Almeida, R. P. P., and Daane, K. M. 2018. Incidence of grapevine leafroll disease: Effect of grape mealybug (Pseudococcus maritimus) abundance and pathogen supply. J. Econ. Entomol. 111:1542-1550.

Court, C. D., Hodges, A. W., Rahmani, M., and Spreen, T. H. 2017. Economic contributions of the Florida citrus industry in 2015-16. Food and Resource Economics Department, University of Florida. https://fred.ifas.ufl.edu/pdf/ economic-impact-analysis/Economic_Impacts_of_the_Florida_Citrus_Industry_ 2015_16.pdf

Farrar, K. 2019. Foundation Plant Services News. Update on red blotch in foundation vineyards. https://fps.ucdavis.edu/newsarticle.cfm?newsid=55

Fenichel, E. P., Richards, T. J., and Shanafelt, D. W. 2014. The control of invasive species on private property with neighbor-to-neighbor spillovers. Environ. Resour. Econ. 59:231-255.

Ferguson, L., and Grafton-Cardwell, E. E. 2014. Page 433 in: Citrus Production Manual. Publication 3539. University of California, Division of Agriculture and Natural Resources, Richmond, CA

Fuchs, M. 2020. Grapevine viruses: A multitude of diverse species with simple but overall poorly adopted management solutions in the vineyard. J. Plant Pathol. 102:643-653.

Fuchs, M., Bar-Joseph, M., Candresse, T., Maree, H., Martelli, G. P., Melzer, M. J., Menzel, W., Minafra, A., Sabanadzovic, S., and ICTV Report Consortium. 2020. ICTV Virus Taxonomy Profile: Closteroviridae. J. Gen. Virol. 101:364-365.
Fuller, K. B., Alston, J. M., and Golino, D. A. 2019. The economic benefits from virus screening: a case study of grapevine leafroll in the north coast of California. Am. J. Enol. Vitic. 70:139-146.

Gabriel, D. W., Gottwald, R. E., Lopes, S. A., and Wulff, N. A. 2020. Bacterial pathogens of citrus: Citrus canker, citrus variegated chlorosis and Huanglongbing. Pages 371-389 in: The Genus Citrus. M. Talon, M. Caruso, and F. G. Gmitter, eds. Woodhead Publishing, Elsevier, Duxford, UK.

Gergerich, R., Welliver, R., Gettys, S., Osterbauer, N., Kamenidou, S., Martin, R. R., Golino, D. A., Eastwell, K., Fuchs, M., Vidalakis, G., and Tzanetakis, I. E. 2015. Safeguarding fruit crops in the age of agriculture globalization. Plant Dis. 99:176-187.

Gibson, R. W., and Kreuze, J. K. 2015. Degeneration in sweetpotato due to viruses, virus-cleaned planting material and reversion: a review. Plant Pathol. 64:1-15.

Hansen, M. 2014. Certified grape stocks in short supply. Good Fruit Grower https://www.goodfruit.com/certified-grape-stock-in-short-supply/

Harper, S., Bixby Brosi, A., Beers, B., and DuPont, T. 2019a. Little Cherry Virus. http:// treefruit.wsu.edu/crop-protection/disease-management/little-cherry-disease/

Harper, S., Smith, T., and Curtiss, R. 2019b. Western X Phytoplasma. http:// treefruit.wsu.edu/crop-protection/disease-management/western-X/

Herrick, C. 2014. High demand drives tree fruit rootstocks shortage. Growing Produce. https://www.growingproduce.com/fruits/high-demand-drives-treefruit-rootstock-shortage/

Hodges, A. W., and Spreen, T. H. 2012. Economic impacts of citrus greening (HLB) in Florida, 2006/07-2010/11. University of Florida, IFAS Extension. https://crec.ifas.ufl.edu/extension/greening/PDF/FE90300.pdf

Horst, K., and Cloyd, R. 2007. Page 83 in: Compendium of Rose Diseases and Pests, 2nd Ed. APS Press, St Paul, MN.

Johnson, R. 2019. 2018 Farm Bill Primer: Specialty Crops and Organic Agriculture. Congressional Research Service. https://crsreports.congress.gov/ product/pdf/IF/IF11317

Jones, R. A. C., and Naidu, R. A. 2019. Global dimensions of plant virus diseases: current status and future perspectives. Annu. Rev. Virol. 6:387-409.

Lee, R. F. 2015. Control of virus diseases of citrus. Adv. Virus Res. 91:143-173.

Maliogka, V., Martelli, G. P., Fuchs, M., and Katis, N. 2015. Control of viruses infecting grapevine. Pages 175-227 in: Advances in Virus Research, Vol. 91. G. Loebenstein and N. Katis, eds. Elsevier, Amsterdam, the Netherlands.

Maliogka, V., Minafra, A., Saldarelli, P., Ruiz-Garcia, A. B., Glasa, M., Katis, N., and Olmos, A. 2018. Recent advances on detection and characterization of fruit tree viruses using high-throughput sequencing technologies. Viruses 10:436.

Martin, R. R., Ellis, M. A., Williamson, B., and Williams, R. N., eds. 2017. Page 65 in: Compendium of Raspberry and Blackberry Diseases and Pests, 2nd Ed. APS Press, St Paul, MN.

Martin, R. R., MacFarlane, S., Sabanadzovic, S., Quito, D., Poudel, B., and Tzanetakis, I. E. 2013. Viruses and virus diseases of Rubus. Plant Dis. 97:168-182.

Martin, R. R., and Tzanetakis, I. E. 2018. High risk blueberry viruses by region in North America: Implications for certification, nurseries and fruit production Viruses 10:342.

McRoberts, N., Figuera, S. G., Olkowski, S., McGuire, B., Luo, W., Posny, D., and Gottwald, T. 2019. Using models to provide rapid programme support for California's efforts to suppress Huanglongbing disease of citrus. Philos. Trans. R. Soc. B 374:20180281.

Mejica, J. 2020. Little cherry disease expected to take a bite out of 2020 crop volume. Good Fruit Grower, https://www.goodfruit.com/little-cherry-diseaseexpected-to-impact-potential-volume-of-2020-cherry-crop/

Morris, A., and Muraro, R. 2008. Economic evaluation of citrus greening management and control strategies. University of Florida, IFAS Extension, Gainesville, FL. https://swfrec.ifas.ufl.edu/hlb/database/pdf/00002432.pdf

Mwiti, F. K., Okella, J. J., Munei, K., and Low, J. 2020. Farmer demand for clean planting material of biofortified and non-biofortified vegetatively propagated crop varieties: The case of sweetpotato. Sci. Afric. 8:e00400.

National Clean Plant Network. 2020a. About the national clean plant network. http://nationalcleanplantnetwork.org/about/

National Clean Plant Network. 2020b. Clean plant centers and programs. http:// nationalcleanplantnetwork.org/National_Clean_Plant_Centers/

National Clean Plant Network. 2020c. Information about the National Clean Plant Network (NCPN) https://www.aphis.usda.gov/aphis/ourfocus/planthealth/ppappdmdpp/sa_ncpn

Nimbolkar, P. K., Awachare, C., Reddy, Y. T. N., Chander, S., and Hussain. F. 2016. Role of rootstocks in fruit production - a review. J. Agric. Eng. Food Technol. 3:183-188.

Ogawa, J. M., Zehr, E. I., Bird, G. W., Ritchie, D. F., Urir, K., and Uyemoto, J. K. 1995. Page 128 in: Compendium of Stone Fruit Diseases. APS Press, St Paul, MN

Olexa, M. T., and Benn, J. T. 2018. Feeling the squeeze: Citrus greening policy in the western hemisphere. Drake J. Agric. Law 23:173-197.

Pethybridge, S. J., Hay, F. S., Barbara, D. J., Eastwell, K. C., and Wisson, C. R. 2008. Viruses and viroids infecting hop: Significance, epidemiology and management. Plant Dis. 92:324-338.

Pietersen, G., Bell, V. A., and Krüger, K. 2017. Management of grapevine leafroll disease and associated vectors in vineyards. Pages 531-560 in: Grapevine Viruses: Molecular Biology, Diagnostic and Management. B. Meng, G. P. Martelli, D. A. Golino, and M. Fuchs, eds. Springer Verlag, Cham, Switzerland.

Pietersen, G., Spreeth, N., Ossthuizen, T., van Rensburg, A., van Revensburg, M., Lottering, D., Rossow, N., and Tooth, D. 2013. Control of grapevine leafroll 
disease spread at a wine estate in South Africa: A case study. Am. J. Enol. Vitic. 64:296-305.

Polashock, J. J., Caruso, F. L., Averill, A. L., and Schilder, A. C., eds. 2017. Compendium of Blueberry, Cranberry, and Lingonberry Diseases and Pests, 2nd Ed. APS Press, St. Paul, MN.

Prengaman, K., and Mullinax, T. J. 2019. X disease devastation strikes Pacific Northwest. Researchers and growers urge aggressive response to epidemiclevel infections. Good Fruit Grower https://www.goodfruit.com/x-diseasedevastation-strikes-pacific-northwest/

Preto, C. R., Sudarshana, M. R., Bollinger, M. L., and Zalom, F. G. 2018. Vitis vinifera (Vitales: Vitaceae) as a reproductive host of Spissistilus festinus (Hemiptera: Membracidae). J. Insect Sci. 18:1-7.

Ricketts, K. D., Gómez, M. I., Atallah, S. S., Fuchs, M. F., Martinson, T., Smith, R. J., Verdegaal, P. S., Cooper, M. L., Bettiga, L. J., and Battany, M. C. 2015. Reducing the economic impact of grapevine leafroll disease in California: identifying optimal management practices. Am. J. Enol. Vitic. 66:138-147.

Ricketts, K. D., Gómez, M. I., Fuchs, M. F., Martinson, T. E., Smith, R. J., Cooper, M. L., Moyer, M., and Wise, A. 2017. Mitigating the economic impact of grapevine red blotch: Optimizing disease management strategies in U.S. vineyards. Am. J. Enol. Vitic. 68:127-135.

Roka, F., Muraro, R., Morris, R. A., Spyke, P., Morgan, K., Schumann, A., Castle, W., and Stover, E. 2009. Citrus production systems to survive greening: Economic thresholds. Proc. Fla. State Hortic. Soc. 122:233-239.
Rubio, M., Martínez-Gómez, P., Marais, A., Sánchez-Navarro, J. A., Pallás, V., and Candresse, T. 2017. Recent advances and prospects in Prunus virology. Ann. Appl. Biol. 171:125-138.

Salifu, A. W., Grogan, K., Spreen, R., and Roka, F. 2012. The economics of the control strategies of HLB in Florida citrus. Proc. Fla. State Hortic. Soc. 125: 22-28.

Seavert, C. F., and Julian, J. W. 2012. Quantifying the economic benefits of the National Clean Plant Network for the tree fruit industry in the Pacific Northwest. Phytopathology 102:S4.155.

Sherman, J., Burke, J. M., and Gent, D. H. 2019. Cooperation and coordination in plant disease management. Phytopathology 109:1720-1731.

Sherman, J., and Gent, D. H. 2014. Concepts of sustainability, motivations for pest management approaches, and implications for communication change. Plant Dis. 98:1024-1035.

Singerman, A. 2019. The real cost of HLB in Florida. Citrus Industry News, http:// citrusindustry.net/2019/07/30/the-real-cost-of-hlb-in-florida/

Singerman, A., Lence, S. H., and Useche, P. 2017. Is area-wide pest management useful? The case of citrus greening. Econ. Perspect. Policy 39:609-634.

Sisterson, M. S., and Stenger, D. C. 2013. Roguing with replacement in perennial crops: conditions for successful disease management. Phytopathology 103:117-128.

Sutton, T. B., Aldwinckle, H. S., Agnello, A. M., and Walgenbach, J. F., eds. 2014 Compendium of Apple and Pear Diseases and Pests, 2nd Ed. APS Press, St Paul, MN.

\section{Fuchs}

School of Integrative Plant Science, Cornell University, Geneva, NY 14456

\section{V. Almeyda}

Micropropagation and Repository Unit, North Carolina State University, Raleigh, NC 27695

\section{Al Rwahnih}

Foundation Plant Services, Plant Pathology Department, University of California, Davis, CA 95616

\section{S. S. Atallah}

Department of Agricultural and Consumer Economics, University of Illinois, Urbana-Champaign, IL 61820

\section{E. J. Cieniewicz}

Plant and Environmental Sciences, Clemson University, Clemson, SC 29634

\section{K. Farrar}

Foundation Plant Services, Plant Pathology Department, University of California, Davis, CA 95616

\section{W. R. Foote}

Crops and Soil Sciences, North Carolina State University, Raleigh, NC 27695

\section{A. Golino}

Foundation Plant Services, Plant Pathology Department, University of California, Davis, CA 95616

\section{I. Gómez}

Charles H. Dyson School of Applied Economics and Management, Cornell University, Ithaca, NY 14853

\section{S. J. Harper}

Department of Plant Pathology, Washington State University, Prosser, WA 99350

\section{K. Kelly}

Department of Agriculture and Markets, Division of Plant Industry, Albany, NY 12205

\section{R. R. Martin}

Department of Botany and Plant Pathology, Oregon State University, Corvallis, OR 97331

\section{T. Martinson}

School of Integrative Plant Science, Cornell University, Geneva, NY 14456

\section{F. M. Osman}

Foundation Plant Services, Plant Pathology Department, University of California, Davis, CA 95616

\section{K. Park}

Charles H. Dyson School of Applied Economics and Management, Cornell University, Ithaca, NY 14853

\section{Scharlau}

Washington Wine Industry Foundation, Cashmere, WA 98815

\section{R. Smith}

University of California, Cooperative Extension, Sonoma County, Santa Rosa, CA 95403-2894

\section{E. Tzanetakis}

Department of Entomology and Plant Pathology, Division of Agriculture, University of Arkansas, Fayetteville, AR 72701

\section{G. Vidalakis}

Department of Microbiology \& Plant Pathology, University of California, Riverside, CA 92521

\section{R. Welliver}

The Pennsylvania Department of Agriculture, Bureau of Plant Industry, Harrisburg, PA 17110 
Umer, M., Liu, J., You, H., Xu, C., Dong, K., Luo, N., Kong, L., Li, X., Hong, N., Wang, G., Fan, X., Kotta-Loizou, I., and Xu, W. 2019. Genomic, morphological and biological traits of the viruses infecting major fruit trees. Viruses 11:515.

United States Department of Agriculture, Agriculture Marketing Service. 2020. What is a specialty crop? https://www.ams.usda.gov/services/grants/scbgp/ specialty-crop.

United States Department of Agriculture, Animal and Plant Health Inspection Service. 2020. Citrus greening. https://www.aphis.usda.gov/aphis/ourfocus/planthealth/ plant-pest-and-disease-programs/pests-and-diseases/citrus/citrus-greening/.

United States Department of Agriculture-National Agricultural Statistics Service. 2020. Florida Citrus Statistics 2018-2019. https://www.nass.usda.gov/Statistics_ by State/Florida/Publications/Citrus/Citrus_Statistics/2018-19/fcs1819.pdf

Vidalakis, G., Gumpf, D. J., Polek, M.-L., and Bash, J. A. 2014. The California Citrus Clonal Protection Program. Pages 117-130 in: Citrus Production Manual. Publication 3539. L. Ferguson and B. Grafton-Cardwell, eds. University of California, Division of Agricultural and Natural Resources, Davis, CA.

Weinstock, D. 2016. Cider apple variety shortage. Good Fruit Grower. https:// www.goodfruit.com/cider-apple-variety-shortage/
Welliver, R., Valley, K., Rickwine, N., Clement, G., and Albright, D. 2014 Expelling a plant pest invader. The Pennsylvania plum pox eradication program, a case study in regulatory cooperation. Pennsylvania Department of Agriculture, Harrisburg, PA.

Wilcox, W. F., Gubler, W. D., and Uyemoto, J. K., eds. 2015. Compendium of Grape Diseases, Disorders and Pests, 2nd Ed. APS Press, St Paul, MN.

Wright, A. A., Cross, A. R., and Harper, S. J. 2020. A bushel of viruses; Identification of seventeen novel putative viruses by RNA-seq in six apple trees. PLoS One 15:e0227669.

Yeh, D. A., Park, K., Gómez, M., and Fuchs, M. 2019. A review of economic studies on pathogen-tested plant materials and clean plant programs for specialty crops. Charles H. Dyson School of Applied Economics and Management, Cornell University, Ithaca, NY. https://dyson.cornell.edu/wpcontent/uploads/sites/5/2020/02/Clean-plant-literature-review-FINAL-VD.pdf.

Zhou, C., da Graça, J. V., Freitas-Astúa, J., Vidalakis, G., Duran-Vila, N., and Lavagi, I. 2020. Citrus viruses and viroids. Pages 391-410 in: The Genus Citrus. M. Talon, M. Caruso, and F. G. Gmitter, eds. Woodhead Publishing, Elsevier, Duxford, UK. 